\title{
Substance Use Category
}

National Cancer Institute

\section{Source}

National Cancer Institute. Substance Use Category. NCI Thesaurus. Code C82499.

A classification scheme based on the use of a particular material or product. 